\title{
Clinical diagnosis of congenital and acquired heart disease in children: Do non paediatrician doctors feel competent?
}

\author{
*Blessing Ofejiro Okperi ${ }^{1}$, Okiroro Ighosewe ${ }^{2}$ \\ Sri Lanka Journal of Child Health, 2017; 46(1): 264-266
}

\begin{abstract}
Background: The diagnosis of congenital and acquired heart disease is almost always first clinical, before confirmation by ancillary investigations by the specialist paediatricians to whom these patients are usually referred. Since early diagnosis and appropriate intervention is the only hope for such children, inability to pick up these children on clinical examination with their usual peculiar clinical features and murmurs connotes a disaster for such children.
\end{abstract}

Objective: To determine if non paediatrician doctors in the Delta state of Nigeria possess the confidence to make clinical diagnoses of congenital or acquired heart disease in children.

Method: An anonymous structured questionnaire was administered to 116 doctors randomly selected from the estimated 600 doctors in both private and public sectors of the Delta state.

Results: Sixty nine (59.5\%) have attempted to diagnose congenital or acquired heart disease by identifying a murmur whilst $47(40.5 \%)$ have never made such an attempt. Forty six (40\%) feel confident in making a clinical diagnosis after examining the child, while $70(60 \%)$ do not feel confident to make such a diagnosis from clinical examination. Twenty nine $(37.7 \%)$ blame their inadequate undergraduate training / clinical exposure for their lack of confidence, 40 (51.9\%) believe such diagnosis is reserved to specialist paediatricians while $8(10.4 \%)$ could not give any specific reasons for their lack of confidence to make such diagnosis.

Conclusion: Only $40 \%$ of non paediatrician doctors in the Delta state of Nigeria feel confident

\footnotetext{
${ }^{1}$ Associate Professor of Paediatrics, ${ }^{2}$ Lecturer, Department of Paediatrics, College of Health Sciences, Delta State University, Nigeria

*Correspondence: ofejiro@yahoo.com

(Received on 03 February 2016: Accepted after revision on 17 March 2016)

The authors declare that there are no conflicts of interest

Personal funding was used in formulating the article. Open Access Article published under the Creative
}

Commons Attribution CC-BY (cc) DOI: http://dx.doi.org/10.4038/sljch.v45i4. of diagnosing congenital or acquired heart disease in children.

(Key words: Clinical diagnosis, murmurs, congenital heart disease, acquired heart disease)

DOI: http://dx.doi.org/10.4038/sljch.v45i4.8067

\section{Introduction}

The incidence of congenital heart disease (CHD) in children in different studies varies from 4-50 per 1000 live births ${ }^{1,2}$. In Nigeria, variations in incidence are documented from different centres ${ }^{3-7}$. Congenital anomalies of the heart and great vessels have a high mortality in the first year of life ${ }^{8}$. Acquired heart disease also varies from centre to centre. The initial diagnosis of congenital and acquired heart disease is usually clinical often by characterizing a murmur among other clinical features. Often the presence of finger clubbing, cyanosis, suffused conjunctivae and failure to thrive tend to call attention to possible heart disease before confirmation by other investigations including $\mathrm{x}$-rays, electrocardiography, echocardiography and cardiac catheterisation. Delta State is one of the states in the Niger Delta region of Nigeria, in the rainforest belt with an estimated population of 4 million people. The state has only 11 paediatricians in both public and private health institutions. Thus, much of the population will be catered to by non paediatricians. The survival of children with congenital or acquired heart disease requires prompt and early diagnosis and appropriate medical and / or surgical interventions early before fatal complications such as Eisenmenger syndrome set in.

\section{Objective}

To determine if non paediatrician doctors in the Delta state of Nigeria possess the confidence to make clinical diagnoses of congenital or acquired heart disease in children.

\section{Method}

A questionnaire was administered to 116 nonpaediatrician doctors randomly selected from the 600 doctors in both government owned and private hospitals in the Delta state. Paediatricians were excluded. The questionnaire included sex of the respondents, medical qualifications and years of medical practice as a doctor, if they have ever clinically diagnosed congenital or acquired heart disease in a child by themselves and if they feel 
confident to make such clinical diagnoses. The responses were collated and presented in simple descriptive proportions.

\section{Results}

The sex distribution of the respondents is shown in Table 1 .

Table 1: Sex Distribution

\begin{tabular}{|l|c|}
\hline \multicolumn{1}{|c|}{ Sex } & Number (\%) \\
\hline Male & $90(77.6)$ \\
\hline Female & $26(22.4)$ \\
\hline
\end{tabular}

The years of practice as a doctor are shown in Table 2.

Table 2: Years of Practice as a doctor

\begin{tabular}{|l|c|}
\hline \multicolumn{1}{|c|}{ Years of practice } & Number (\%) \\
\hline Less than 5 & $21(18.1)$ \\
\hline $5-10$ & $20(17.2)$ \\
\hline $10-20$ & $27(23.3)$ \\
\hline More than 20 & $48(41.4)$ \\
\hline
\end{tabular}

The professional qualifications of the respondents are shown in Table 3.

Table 3

Professional qualifications of respondents

\begin{tabular}{|l|c|}
\hline \multicolumn{1}{|c|}{ Qualification } & Number (\%) \\
\hline MBBS & $61(52.6)$ \\
\hline Post Graduate Fellowship & $27(23.3)$ \\
\hline Others: MPH, MSc, PhD, etc. & $28(24.1)$ \\
\hline
\end{tabular}

To the question "Have you ever attempted to diagnose congenital or acquired heart disease by identifying a murmur?" 69 (59.5\%) responded positively and 47 (40.5\%) responded negatively.

To the question "Do you feel confident to clinically diagnose congenital or acquired heart disease in children?" 46 (40\%) responded positively and 70 $(60 \%)$ responded negatively.

The stated reasons for lack of confidence to clinically diagnose heart disease in children are shown in Table 4.

Table 4

Reasons for lack of confidence to clinically diagnose heart disease in children

\begin{tabular}{|l|c|}
\hline \multicolumn{1}{|c|}{ Reason for lack of confidence } & No. (\%) \\
\hline $\begin{array}{l}\text { Inadequate undergraduate training } \\
\text { /clinical exposure }\end{array}$ & $29(37.7)$ \\
\hline $\begin{array}{l}\text { Diagnosis should only be made by } \\
\text { specialist paediatricians }\end{array}$ & $40(51.9)$ \\
\hline No specific reason & $08(10.4)$ \\
\hline
\end{tabular}

Additional analyses along the lines of different Specialities was not possible since all the Specialities had only one or two persons per
Speciality except Obstetrics and Gynaecology that had three respondents.

\section{Discussion}

It is interesting that there have not been similar studies in the literature that sought to evaluate the perceived competence of doctors in diagnosis of acquired and congenital heart disease in children. The diagnosis of congenital and acquired heart disease in children begins with appropriate history taking and a detailed and confident clinical examination especially of the cardiovascular system. Most cardiac diseases have distinct historical and clinical patterns often with peculiar murmur characters, points of maximal intensity and radiation. Since most of these children will inevitably be seen by non paediatricians, due to the paucity of paediatricians in Delta State, it is most worrying that as much as $60 \%$ of these doctors are not confident to make these initial diagnoses before subsequent referrals to appropriate specialists. This means that children with these diseases will most likely be misdiagnosed and have inappropriate treatment or delayed referrals until it is often too late. That $37.7 \%$ blame their lack of competence and confidence on their poor undergraduate training / exposure to basic cardiology rings a bell. Even more worrisome is the fact that $51.9 \%$ believe that such ordinary clinical diagnosis is beyond their competence i.e. reserved for specialist paediatricians.

\section{Conclusions}

Only $40 \%$ of non paediatrician doctors in the Delta state of Nigeria feel confident of diagnosing congenital or acquired heart disease in children.

\section{Acknowledgements}

We acknowledge the Nigerian Medical Association, Delta state branch for the permission to administer the survey questionnaire to members and for the individual doctors for their consent to participate in the study.

\section{References}

1. Hoffman JIE, Kaplan S. The incidence of congenital heart disease. Journal of the American College of Cardiology 2002; 39: 1890-900.

http://dx.doi.org/10.1016/S07351097(02)0 1886-7

2. Behrman RE, Kliegman RM, Arvin AM, editors. 1996: Nelson's Textbook of Paediatrics. 15 th ed. W.B Saunders. 1996: Chapter 384, Page1286.

3. Okoroma EO. Congenital heart diseases In: Azubuike JC, Nkanginieme KEO (2007): Paediatrics and child health in a 
tropical region, African educational services, Owerri, Nigeria. $2^{\text {nd }}$ edition. 33.

4. Okperi BO, Pattern of congenital heart diseases in Delta state university teaching hospital, Oghara, Nigeria. Continental Journal of Tropical Medicine 2012; 6(1):48-50.

5. Ibadin MO, Sadoh WE, Osarogiagbon W. Nigeria Journal of Pediatrics 2005; 32(2): 29-32.

6. Jaiyesimi F, Antia AU, Congenital heart disease in Nigeria: a ten year experience of UCH, Ibadan. Annals of Tropical Pediatrics 1981; 1(2): 77-85.

PMid: 6185056
7. Kolo PM, Adeoyo PO, Omotosho AB, Afolabi JK. Pattern of congenital heart disease in Ilorin, Nigeria. Niger Postgraduate Medical Journal 2012: 19(4): $230-4$.

PMid: 23385679

8. Mitague NI, Cardoso SM, Meyer F, Ultramari FT, Araujo FH, Rozkowisk I, et al. Epidemiological study of congenital heart defects in children and adolescents. Analysis of 4,538 cases. Arq. Bras. Cardiol. 2003; 80(3): 295-300. 